\title{
Traumatology
}

\section{Perceived resistance to experiences of trauma and crisis. A study comparing multiple life events. \\ --Manuscript Draft--}

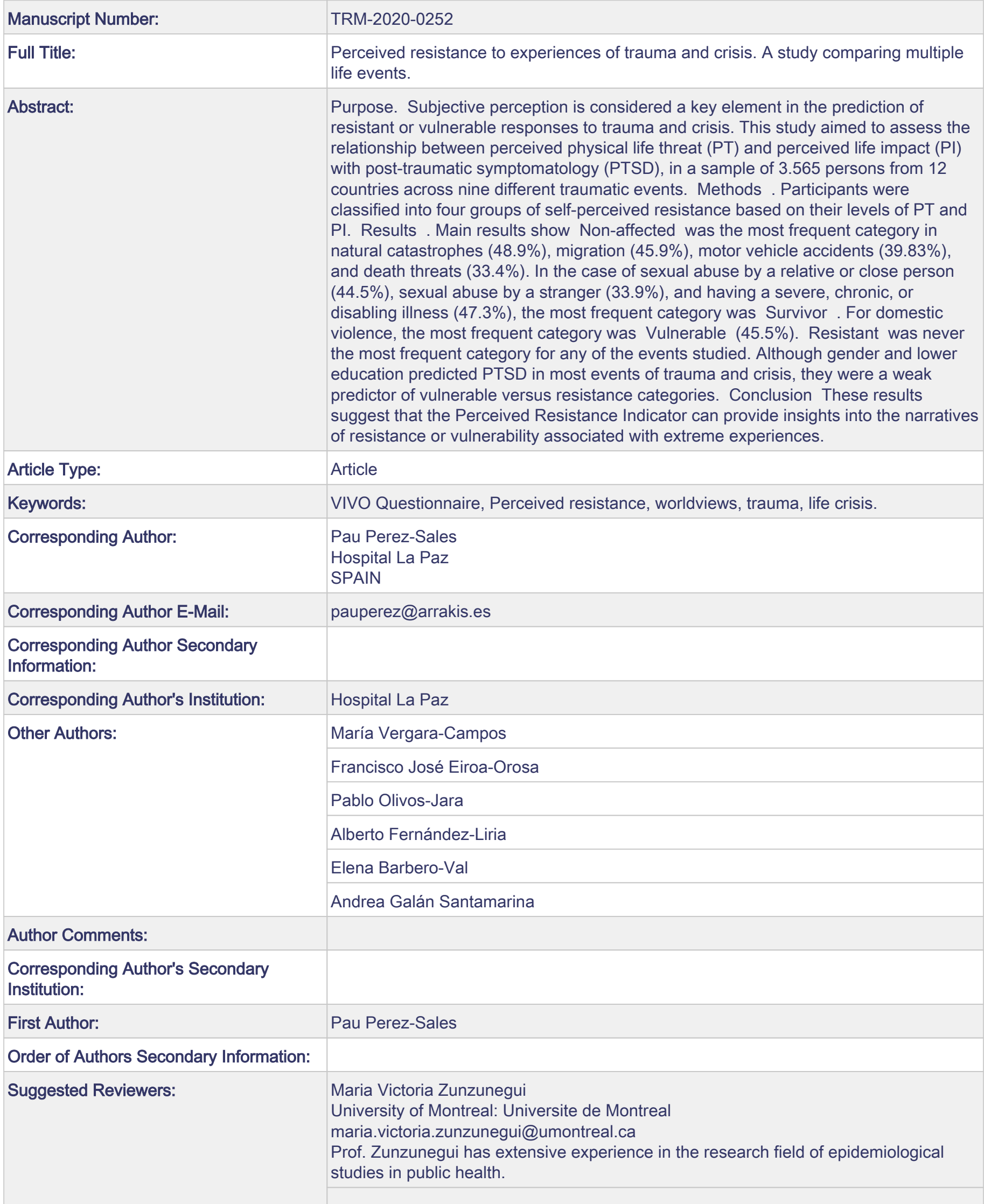


Carmelo Vázquez

Universidad Complutense de Madrid

cvazquez@psi.ucm.es

Prof. Vazquez has worked extensively with the traumatic response of the human being and worked with it from positive psychology.

Opposed Reviewers:

Order of Authors:

Pau Perez-Sales

María Vergara-Campos

Francisco José Eiroa-Orosa

Pablo Olivos-Jara

Alberto Fernández-Liria

Elena Barbero-Val

Andrea Galán Santamarina 
Dear editors,

We would like to submit the manuscript "Perceived resistance to experiences of trauma and crisis. A study comparing multiple life events" for publication in Traumatology Journal. The research is based on findings of the V.I.V.O. project, a population based study on the impact of extreme experiences on basic beliefs, worldviews and coping strategies.

In this manuscript, we explore the relationship between perceived life threat and perceived life impact and its relationship with posttraumatic symptomatology on a sample of 3.565 persons from 12 countries across 9 different events. We believe that our findings will be of great interest for our trauma colleagues as they provide unique data on the importance of subjective perception of threat and impact in the understanding of trauma responses.

The manuscript has not been published elsewhere; it has not been submitted simultaneously for publication elsewhere and is not under review at another publication. All co-authors have seen and agreed with the contents of the manuscript and there is no financial interest to report.

Thank you for your consideration in this matter. We look forward to receiving your reply.

Yours faithfully

Maria Vergara Campos 
Perceived resistance to experiences of trauma and crisis. A study comparing multiple life events.

\section{Pau Pérez-Sales ${ }^{1}$, Maria Vergara-Campos², Francisco José Eiroa-Orosa ${ }^{3}$, Pablo Olivos-Jara ${ }^{4}$, Alberto Fernández-Liria ${ }^{5}$, Elena Barbero-Val ${ }^{6}$, Andrea Galán- Santamarina ${ }^{7}$.}

${ }^{1}$ Director of VIVO Project. Community Action Group (GAC), Madrid.

${ }^{2}$ EXIL Center, Barcelona.

${ }^{3}$ Section of Personality, Evaluation and Psychological Treatment Department of Clinical Psychology and Psychobiology, Universitat de Barcelona.

${ }^{4}$ Castilla-La Mancha University, Albacete.

${ }^{5}$ Department of Psychiatry, Principe de Asturias University Hospital, Alcalá de Henares.

${ }^{6}$ Community Action Group (GAC), Madrid. www.psicosocial.net

${ }^{7}$ Community Action Group (GAC), Madrid. www.psicosocial.net

Keywords: VIVO Questionnaire, Perceived resistance, worldviews, trauma, life crisis.

Correspondence: Pau Pérez Sales, VIVO Project. Community Action Group (GAC), Mental Health and Human Rights Resource Center, Dulcinea, 69, 1º A, Madrid 28020. E-mail: pauperez@ runbox.ecpm

Acknowledgements and funding: The VIVO Project has received a grant from the Ministry of Science and Technological Innovation, through I+D Projects (PSI2008-05548).

Conflict of interest: On behalf of all authors, the corresponding author states that there is no conflict of interest. 
Perceived resistance to experiences of trauma and crisis. A study comparing multiple life events.

\section{Introduction}

It is well known that the majority of the population has experienced one or more extreme experiences throughout their life (Atwoli et al., 2015; Kilpatrick et al., 2013). Available data also show that the vast majority of people usually develops a resilient response (Bonanno et al., 2002, 2011), although this changes with the different types of traumatic experiences(Breslau et al., 1998). The European Study of the Epidemiology of Mental Disorders showed that $51.8 \%$ of women and $48.2 \%$ of men had been exposed to at least one severe traumatic experience in their lifetimes. In comparison, only $1.7 \%$ of women and $0.5 \%$ of men developed post-traumatic stress disorder (PTSD) as a consequence(Alonso et al., 2004; Darves-Bornoz et al., 2008). Other studies confirm similar results in western contexts (Atwoli et al., 2015; Cox et al., 2014).

Previous research studies on resistance to stress suggested that cognitive and personal factors (hardiness, salutogenesis and others) were more relevant in the prediction of trauma response than the stressor (Antonovsky, 1979; Kobasa et al., 1981). Contemporary trauma theory has confirmed that the impact of traumatic experiences differs depending on the type of experience (Keshet et al., 2019; National Collaborating Centre for Mental Health, 2005; Nordstrand et al., 2019). Also there seems to be a relationship between the severity of the threat and the psychological consequences derived from the experience (Bryant et al., 2019; Lanius et al., 2017; Tran et al., 2019).

Nevertheless, there is also an increasing body of evidence suggesting that the subjective perception of vital impact of an event is a critical element in understanding the response to trauma and, for some authors, this subjective perception has a more significant 
impact than the particular characteristics of these events (Ozer et al., 2003; Weathers et al., 2007). For instance, when distinguishing between Life Threat and Subjective Perception of Life Threat, there is evidence that the second is a better predictor of post-trauma consequences among people surviving disasters (Havenaar et al., 2003), violent assaults (Johansen et al., 2006), terrorist attacks (Heir et al., 2016), sexual abuse (Klump, 2006; Ullman et al., 2007), and motor vehicle accidents (Ehlers et al., 1998; Schnyder et al., 2001).

The subjective perception of experience will be determined, in turn, by multiple psychosocial elements, especially by the emotions experienced at the time when the trauma occurred and the social environment in which the person processed the event. Indeed, it has been observed that the experiences of indignity or humiliation, even in the absence of life threat, may be decisive in the development of post-traumatic symptoms in survivors of political repression and torture(Lee et al., 2001; Saraiya et al., 2016), homelessness (Fazel et al., 2008) and victims of sexual violence (Frazier, 2003). Among people displaced by political violence or disasters, loss of sense of control over their future and overcrowding in refugee camps for long periods, leading to depersonalisation or lack of privacy, were better predictors of post-traumatic symptoms than the severity of the threat to life (Silove et al., 2007; Vazquez et al., 2005).

Both perspectives, one focused on the characteristics of the event, and another focused on individual subjectivity, have strong arguments to their credit. The question is how they interact. Large population-based studies have shown, for instance, that sexual abuse, when compared with traffic accidents, increases by five times the risk of suffering post-traumatic stress consequences (National Collaborating Centre for Mental Health, 2005). However, it is also clear that, while people surviving minor traffic accidents can survive without major life-long psychological scars, people who have suffered chronic sexual abuse can develop resilient responses. Therefore, there is an interaction between the characteristics of the event and the subjective perception of the person, which has to date not 
been possible to capture due to the lack of large population-based studies that include both variables and multiple types of potentially traumatic events.

This study aims to be an initial step in this direction. It considers that a specific person may be resistant to a particular event and vulnerable to another. We do not attempt to define the characteristics of resistant or vulnerable people individually, but rather to identify some of the specific characteristics of the interaction between the person and the environment that foster a resilient response (Bonanno et al., 2011; Turner et al., 2004). On this basis, it will be possible to define different response profiles for each of the different types of events. Also, available findings suggest that this kind of response will also vary according to gender (Christiansen et al., 2015; Olff, 2017; Tolin et al., 2006), age (Maercker et al., 2004) and educational level and increase with accumulative trauma (Kira, 2019; Shalev et al., 2019).

We believe that this new perspective can capture some of the richness in the interaction between objective and subjective characteristics of situations in which severe trauma and life crisis have occurred, and can help explain the responses of vulnerability or resistance to trauma.

\section{Method}

\section{Procedure}

The VIVO project (Ontological Vital Impact Assessment, VIVO by its initials in Spanish) is an international collaborative study on the impact of experiences of trauma, crisis and loss in human identity and worldviews. The project is based in a network of public health hospitals in Madrid (Spain) and led by the Community Action Group (GAC), an organisation created in 1997 linked to the field of psychosocial and community work, mental health, and human rights. 
The VIVO questionnaire was developed as a tool to assess the impact of extreme experiences in the worldviews, identity and basic beliefs on both general population and survivors. For its validation, the VIVO questionnaire was distributed through the project website (http://www.psicosocial.info) and systematically publicised in more than 1.400 internet sites randomly selected from general population social forums, major social networks, and distribution lists. Also, there was a permanent link on the website of the Community Action Group (CAG) research area (http://www.psychosocial.info/) that referred directly to the questionnaire where the public, in general, could answer the questionnaire and receive feedback on the results. Procedures for recruitment and the overall context of the project have been described in detail elsewhere (Pérez-Sales et al., 2012).

\section{INSERT FIGURE 1 AROUND HERE}

\section{Participants}

A total of 3.565 participants took part in this study (Figure 1). The sample was obtained from 12 countries, mainly from Spain (32.2\%), Argentina (18.2\%), Mexico (11.5\%), Chile (10.1\%), Colombia (9.7\%), Venezuela (2.9\%), and Peru (2.8\%). The mean age was 28 years $(\mathrm{SD}=9.74)$, and $49.1 \%$ were women. Young people (between 16 to 25 years) represented $49.2 \%$ of the sample, and $50.8 \%$ were adults (between 26 to 65 years). The majority were single $(65.6 \%)$, had a secondary education level or higher $(65 \%)$ and described themselves as middle class (62.2\%). Regarding ideology, 34.5\% perceived themselves as left-wing, and $20.9 \%$ considered themselves of right-wing ideology. Also, while $57.5 \%$ did not practice any religion, from those who described themselves as religious, most were catholic (32\%). 


\section{Definitions}

A traumatic experience is defined as an event that constitutes a threat to the physical or psychological integrity of the person, often associated with confusing emotions that are usually unspeakable and often perceived as incomprehensible to others. It may potentially question the survivors' identity or one or more underlying assumptions of their human worldviews, particularly their sense of security, and it may involve a questioning of the sense of life and world (Pérez-Sales et al., 2012). We have also included experiences of loss (death of a friend or relative due to disease, the murder of a close person, or forced disappearance) and crises (such as divorce or separation, migration, or suffering a severe or chronic disease). Although they are usually are not included under the definition of trauma, but that also involves a component of physical threat and a challenge to the person's identity and human worldviews.

\section{Instruments}

- PTSD Checklist-Civilian Version (PCL-C), a 17-item scale that assesses the presence of symptoms of post-traumatic stress disorder(Weathers et al., 1991) using DSM-IV criteria using a 5-point (1-5) scale range from (1) Not at All-(5) Extremely.

- The Inventory of Extreme Experiences (Pérez-Sales et al., 2012), part of the VIVO toolbox, collects data on 24 experiences linked to trauma, crisis or loss, including data on the severity of the traumatic experience measured by two variables: a) Perception of physical life Threat (PT), ranked from (1) low to (4) extreme; and b) Perception of life Impact (PI), also in four levels (1) I do not consider myself affected, (2) I was affected in the past but not now, (3) There are aspects that still strongly affect me, and (4) This experience has decisively changed my way of seeing life. For this study, we included nine experiences that were directly related to the perception of life threat: road traffic accidents; natural catastrophes; death, assault or beating threats, domestic violence; 
sexual abuse by a stranger; sexual abuse by a family member; severe, chronic or disabling disease; divorce or separation; and migration for economic reasons.

Two measures were derived from these data:

- The Average Score of Traumatic Events (ASTE) is an overall measure that combines the number of events and severity in an indicator to assess the influence of the accumulation of extreme experiences in the response that people have to them. Algorithms for calculations sent on request.

- Self-Perceived Resistance (SPR) is an indicator based on the interaction of PT and PI variables, with four categories: Resistant, Survivor, Vulnerable and Non-affected (see Figure 2). When a person had an high perception of physical threat towards a traumatic experience (high PT) but did not consider that this experience had a significant impact on their life (low PI), we suggest that this person perceives himself or herself as Resistant to such experience. However, if this person also considers that the event had a high impact on their lives (high PI), he or she could have a Survivor perception of himself or herself. If a person had a low perception of physical threat (low PT) and a perception of high impact on their life (high PI), this person is deemed to be Vulnerable to that traumatic event. Finally, if both threat and perception of impact are reported as low (low PI), the person is considered as Non-Affected by the experience.

\section{INSERT FIGURE 2 AROUND HERE}

\section{Statistical Analysis}

We performed descriptive statistics for each extreme experience. Linear regression analyses were also performed for each life event with those variables whose correlation with PTSD proved to be significant in bivariate analysis. We used PTSD as the dependent variable and the Average Score of Traumatic Events (ASTE), Perception of Life Threat (PT), and 
Perception of Life Impact (PI) as independent variables. Gender, age, and educational level were introduced as potentially confounding variables by using cross tables and chi-squared test. The alpha risk assumed was 5\% for all calculations. All analyses were performed using SPSS 23 for Windows.

Ethical elements. Written informed consent was collected for each participant. Data of respondents and results were stored in separate databases, stored in the premises of the Complutense University, and submitted to approval by the Spanish Data Protection Office (RegNum 56325). The protocol was approved by the IRB of University Hospital La Paz $(34 / 765 / 2017)$.

\section{Results}

The most common events reported in our sample (Table 1) were divorce (35\%), threats of death, assault or beating (34.4\%), motor vehicle accidents (27.6\%). The less common ones were sexual abuse by a relative or a close person $(6.5 \%)$ and by a stranger $(5.1 \%)$

The experiences in which a higher proportion of respondents report long-lasting consequences (Table 1; PI, Column 3) are domestic violence (46.2\%), sexual abuse by a family member or a close person (39.5\%), and sexual abuse by a stranger (35.3\%). The experiences that more frequently changed the way that respondents understand life challenging human worldviews (Table 1; PI, Column 4) were severe, chronic or disabling illness (43.4\%), sexual abuse by a relative or a close person (33.8\%), domestic violence (30.4\%), sexual abuse by a stranger (29.4\%) and migration (29.2\%). By contrast, the events in which people declared in a higher proportion to be affected at the time of the events but not anymore (Table 1, PI, Column 1) were natural catastrophes (51.4\%), motor vehicle accidents (47.2\%) and threats of death or assault (42.3\%). 


\section{INSERT TABLE 1 AROUND HERE}

\section{Perception of Life threat, Perception of Impact and Post-traumatic related symptoms.}

We performed Spearman correlations to screen which variables correlated significantly with PTSD. Only those that were statistically significant were included in the regression analyses (Table 2). Age was excluded in all regression models $(\rho=-.0008 ; n s)$. Perception of Life Threat (PT) $(\rho=.17 ; n s)$ was excluded for motor vehicle accidents. Linear regressions analysis (table 2) show that Perception of Life Threat (PT) only predicted PTSD in death threats $(\beta=.07 ; p<.05)$, domestic Violence $(\beta=.13 ; p<.01)$, severe, chronic or disabling illness $(\beta=.12 ; p<.01)$, divorce $(\beta=.2 ; p<0.001)$ and migration $(\beta=.16 ; p<.001)$. The Perception of Life Threat (PT) does not predict PTSD in natural disasters $(\beta=.1 ; n s)$, sexual abuse by strangers $(\beta=.04 ; n s)$ and sexual abuse by a relative $(\beta=.08 ; n s)$. The Perception of Life Impact (PI) predicts PTSD for all events of trauma and loss except for migration $(\beta=.08$; $n s)$.

The Average Score of Traumatic Events (ASTE), as a measure of the overall weight of traumatic events, predicts PTSD-related symptoms for motor vehicle accidents $(\beta=.11$; $p<.01)$; natural disasters $(\beta=.15 ; p<.05)$; serious, chronic and disabling disease $(\beta=.16$; $p<.001)$; and divorce or separation $(\beta=.11 ; p<.01)$.

Gender was a predictor of PTSD in migration $(\beta=-.22 ; p<0.001)$, death, assault or beating threats $(\beta=-.12 ; p<.001)$ and motor vehicle accidents $(\beta=-.17 ; p<.001)$. Level of education was also a predictor in most of the experiences except for natural disasters $(\beta=-$ $.1 ; n s)$. 


\section{Self-Perceived Resistance in Extreme Events}

The unit of analysis is events. Therefore, participants can score in more than one category of Perceived Resistance if they experienced more than one event of trauma, crisis, or loss. Overall and considering scores across all events, $31.6 \%(\mathrm{n}=1.834)$ of participants were classified as Non-affected by the experiences (low threat/low impact), $28.8 \%(n=1.669)$ as Survivors (medium-severe threat/medium-severe impact), $27 \%(\mathrm{n}=1.564)$ as Vulnerable (low threat/high impact), and 12.6\% ( $\mathrm{n}=728)$ as Resistant (high threat/low impact).

Figure 3 compares each extreme event for every category of perceived resistance (Non-affected, Survivor, Resistant and Vulnerable). In the case of natural catastrophes (48.9\%), migration (45.9\%), motor vehicle accidents (39.83\%), and death threats $(33.4 \%)$, most participants were Non-affected. Concerning sexual abuse by a relative or close person (44.5\%), sexual abuse by a stranger (33.9\%), and having a severe, chronic, or disabling illness (47.3\%), most respondents were Survivors. In the case of domestic violence, the most frequent category was Vulnerable $(45.5 \%)$. Resistant was never the most frequent category for any of the events.

\section{INSERT FIGURE 3 AROUND HERE}

Table 3 compares self-perceived resistance by gender and educational level, the only two variables that showed positive correlations in bivariate analysis. In overall there are more women than men in the Vulnerable and Survivors categories in Motor vehicle accidents $\left(\square^{2}=\right.$ 35.3, $p<.001)$, Natural disasters $\left(\square^{2}=25.1, p<.001\right)$ and Death assault $\left(\square^{2}=97.9, p<.001\right)$. Those are the categories associated with the most significant subjective impact as compared to the actual perception of threat. Unexpectedly, there are no differences by gender in Domestic Violence $\left(\square^{2}=3.6, n s\right)$, Sexual assault by a stranger $\left(\square^{2}=0.1, n s\right)$ and Sexual assault by a relative $\left(\square^{2}=6.6, n s\right)$, suggesting that they are experiences linked to a high 
perception of threat and impact for both genders. Regarding crisis, there are no differences by gender in Divorce of Separation, $\left(\square^{2}=3.8, n s\right)$, Migration $\left(\square^{2}=5.4, n s\right)$ and there are more survivors and vulnerable among women in Serious, Chronic or disabling disease $\left(\square^{2}=\right.$ $13.4, p<.001)$. Although there is a tendency to have more Survivors and Vulnerable population among the lower educated groups, this only reaches statistical significance in Natural Disasters $\left(\square^{2}=15.1, p<.001\right)$.

\section{INSERT TABLE 3 AROUND HERE}

Table 4 shows the ANOVA analysis of PTSD scores by the experience of trauma, crisis and loss and self-perceived resistance. For most trauma events Survivors and Vulnerable population score higher than Resistant and Non-Affected (Motor vehicle accidents F=8.4, $p<.001$, Natural disasters F=7.2, $p<.001$, Death assault F=28.9, $p<.001$, Domestic Violence $\mathrm{F}=10.7, p<.001)$. This confirms the idea that it is the subjective perception of impact and not the actual threat what determines PTSD scores. There are two notable exceptions. Sexual assault by a stranger $(\mathrm{F}=1.4, n s)$, and Sexual assault by a relative or close friend $(\mathrm{F}=2.6, n s)$ where PTSD scores are similar for all categories of self-perceived resistance. This suggests that Sexual assault is a distinct category of traumatic events where there is a traumatic impact irrespective of whether the person perceives him or herself as vulnerable or resistant. Resistant people also score high in PTSD, meaning that resilience is a narrative related to what the person tells to him or herself, and it does not necessarily mean less post-traumatic symptoms. Finally, for all crisis events, Survivors score higher than all other groups (Serious, Chronic or disabling illness $\mathrm{F}=9.5, p<.001$, Divorce or separation $\mathrm{F}=26.8, p<.001$, Migration $\mathrm{F}=3.9, p<.001)$ suggesting that crisis are associated with PTSD only when there is a high perception of threat. 


\section{Discussion}

Our data offer a unique epidemiological perspective on the different profiles of resistance and vulnerability answers in experiences of trauma and crisis (Table 1). In an international Spanish-Speaking sample, survivors of domestic violence, sexual abuse by a stranger and by relative or a close person, and divorce or separation (interpersonal experiences) have a higher perception of life impact than survivors of natural disasters or motor vehicle accidents (non-interpersonal traumatic events). The only exception is a severe, chronic, or disabling illness. Overall, our findings confirm that experiences of interpersonal violence are associated with a higher impact on worldviews (Breslau et al., 2004; Chapman et al., 2012). These are experiences that confront the person with his or her vision of others and connect with experiences of intimacy, trust and care (Botsford et al., 2019), sense of security and bonding (Barazzone et al., 2018), predictability and sense of control over one's life (Frazier, 2003) among others.

On the other hand, severe chronic and disabling illness has a different impact as it uniquely confronts the person with death and eventually, the meaning of life (Park, 2010). This is especially relevant as previous studies have suggested a low correlation of LifeThreatening diseases with PTSD (Breslau et al., 2004). Our results emphasize the importance of systematically including also a perspective based on measuring the impact on worldviews besides standard clinical diagnosis. Our data also confirm that sexual violence is a traumatic event with the highest personal impact, especially by a friend or relative. However, it adds a new perspective: domestic violence and divorce can have very similar severity of impacts in terms of vulnerability and resistance. Although the number of women who report it is much higher, the impact on worldviews is observed for both men and women. Other forms of gender-based violence and abuse should also be included in future studies on sexual abuse (Scott et al., 2018). 
The perception of life impact (PI) is a constant powerful predictor for all the experiences, with the only exception of migration. By contrast, the actual Perception of Life threat (PT) is not relevant for most extreme experiences, either being expelled from the model or having a marginal contribution to the overall explained variance. This includes those events where security is central, like motor vehicle accidents or natural catastrophes. Interestingly, Life Threat is a predictor of PTSD in experiences of crisis: domestic violence, divorce, severe, chronic, or disabling illness, and migration. Our results support previous findings (Frese et al., 2004; Johansen et al., 2006; Ullman et al., 2007) showing that in order to understand the harm caused by extreme experiences, in general, it is not enough to consider the perception of life threat (Boals et al., 2015). Our data are also congruent with previous studies on rape and sexual abuse, indicating that it is the perception of impact but not the perception of life threat which predicts post-traumatic symptoms and remission (Müller et al., 2018).

Our results do not support the idea that the accumulative impact of traumas as measured by the ASTE will always predict PTSD-related symptoms. This is only so for motor vehicle accidents, natural disasters, severe, chronic, or disabling disease, and divorce. For all other experiences of trauma and crisis, including sexual abuse, our combined indicator of the number of traumatic events and the impact of each of them does not significantly contribute to predicting PTSD. Although according to literature (Shalev et al., 2019)'(Frissa et al., 2013) living more than one extreme experience is related to the onset of PTSD-related symptoms, our study shows that having experienced multiples different traumas does not necessarily predict the severity and type of response to trauma in the present. This non-linear relationship might help explain contradictory results in the literature. Self-Perceived Resistance (SPR) does not change with age, but it is related to gender and educational level. Those considered as Non-Affected are mostly men and with a high educational level. Those identified as Survivors or Vulnerable are mostly women and 
people with a low educational level. Previous reports indicate a relationship between clinical impact with gender and low educational level (Shalev et al., 2019). Our results enlarge the perspective suggesting a similar pattern concerning resilient and vulnerable answers.

The percentage of resilient versus vulnerable people change across different trauma and crisis experiences. Across all experiences of trauma and loss, the correlation between a real threat and subjective impact is moderate. Around $27 \%$ of people declare a severe subjective impact, although reporting that the actual threat was low. This combination might act as a sentinel indicator of the population eventually most in need of support (not necessarily clinical) after the experience. Similarly, $16 \%$ perceive themselves as mostly unaffected as compared to the actual high severity of the threat. In between, there are the categories in which threat and subjective impact are more or less proportional. Our data confirm the importance of narratives to understand the impact of trauma and crisis, going beyond PTSD circumscribed models (Boals et al., 2015). Sexual assault seems a distinct category where the clinical impact is high irrespective of the perception of vulnerability or resistance. Again, the idea that despite having post-traumatic symptoms as much severe as other victims, some persons built a narrative of resistance by probably normalizing those symptoms and assuming them as part of the healing process. Finally, there is a controversy on whether certain crisis events (like cancer, divorce, or migration) should be considered traumatic events. Our results show that this is only the case when they are associated with an actual perception of life-threat. It is not the crisis itself, but the threat what makes them traumatic.

We propose the Perceived Resistance Indicator (PRI) as a simple measure to study the intersection between the threatening characteristics of the experience and the subjective experience of the survivor. 
Furthermore, this perspective allows a new way of understanding preventive action and resource planning. The classic approach focuses on early detection of most affected cases. However, these are often populations that will not seek help nor attend services, as they do not have a demand. The PRI can help to analyse profiles of demand better and improve service planning. It can also help in profiling the impact of different live events beyond the classical distinction between interpersonal and non-interpersonal experiences.

\section{Limitations}

This study suffers from general limitations on the use of self-reports and retrospective methodology in the study of trauma. Furthermore, the use of a self-selected Internet sample could have caused a of self-selection effect that would explain the high prevalence of some of the traumatic events evaluated by the ASTE. However, the correlational nature of the study allows us to use these data, since our objectives are related to subjective perceptions of impact and threat and their relationship with post-traumatic symptoms regardless of its population prevalence.

\section{Conclusions}

Although the perception of physical threat and the perception of life impact are both relevant in the prediction of the appearance of post-traumatic-related symptoms, the second one, linked to the worldviews and narrative built upon time, is what best explains symptomatology. Interpersonal and chronic experiences that imply a change in expectations for the future and challenge the understanding of oneself or others have a more profound impact as compared to experiences that mainly question security and predictability. Selfperceived resilience changes across types of events of trauma and loss, providing epidemiological support to the ecological and interactive nature of the human response to trauma and useful insights into the narratives of resistance or vulnerability associated with 
extreme experiences. It can also potentially provide a new outlook in the planning of services. 


\section{References}

Alonso, J., Angermeyer, M. C., Bernert, S., Bruffaerts, R., Brugha, T. S., Bryson, H., de Girolamo, G., de Graaf, R., Demyttenaere, K., Gasquet, I., Haro, J. M., Katz, S. J., Kessler, R. C., Kovess, V., Lepine, J. P., Ormel, J., Polidori, G., Russo, L. J., Vilagut, G., \& Almansa, J. (2004). Prevalence of mental disorders in Europe: results from the European Study of the Epidemiology of Mental Disorders (ESEMeD) project. Acta Psychiatrica Scandinavica, 109, 21-27.

Antonovsky, A. (1979). Health, Stress and Coping. Jossey-Bass.

Atwoli, L., Stein, D. J., Koenen, K. C., \& McLaughlin, K. A. (2015). Epidemiology of posttraumatic stress disorder: Prevalence, correlates and consequences. Current Opinion in Psychiatry, 28(4), 307-311.

https://doi.org/10.1097/YCO.0000000000000167

Barazzone, N., Santos, I., Mcgowan, J., \& Donaghay-spire, E. (2018). The links between adult attachment and post-traumatic stress : A systematic review. 1-17. https://doi.org/10.1111/papt.12181

Boals, A., Schuettler, D., \& Southard-Dobbs, S. (2015). Construing trauma as a doubleedged sword: how narrative components of autobiographical memory relate to devastation and growth from trauma. Clinical Perspectives On Autobiographical Memory, 65-84. https://doi.org/10.1017/cbo9781139626767.005

Bonanno, G. A., Westphal, M., \& Mancini, A. D. (2011). Resilience to Loss and Potential Trauma. Annual Review of Clinical Psychology, 7(1), 511-535.

https://doi.org/10.1146/annurev-clinpsy-032210-104526

Bonanno, G. A., Wortman, C. B., Lehman, D. R., Tweed, R. G., Haring, M., Sonnega, J., Carr, D., \& Nesse, R. M. (2002). Resilience to loss and chronic grief: A prospective study from preloss to 18-months postloss. Journal of Personality and Social 
Psychology, 83(5), 1150-1164. https://doi.org/10.1037//0022-3514.83.5.1150

Botsford, J., Steinbrink, M., Rimane, E., Rosner, R., Steil, R., \& Renneberg, B. (2019). Maladaptive Post-traumatic Cognitions in Interpersonally Traumatized Adolescents with Post-traumatic Stress Disorder: An Analysis of "Stuck-Points". Cognitive Therapy and Research, 43(1), 284-294. https://doi.org/10.1007/s10608-018-9928-3

Breslau, N, Kessler, R. C., Chilcoat, H. D., Schultz, L. R., Davis, G. C., \& Andreski, P. (1998). Trauma and posttraumatic stress disorder in the community: the 1996 Detroit Area Survey of Trauma. Archives of General Psychiatry, 55(7), 626-632.

Breslau, Naomi, Peterson, E. L., Poisson, L. M., Schultz, L. R., \& Lucia, V. C. (2004). Estimating post-traumatic stress disorder in the community: Lifetime perspective and the impact of typical traumatic events. Psychological Medicine, 34(5), 889-898. https://doi.org/10.1017/S0033291703001612

Bryant, R. A., Felmingham, K. L., Malhi, G., Andrew, E., \& Korgaonkar, M. S. (2019). The distinctive neural circuitry of complex posttraumatic stress disorder during threat processing. Psychological Medicine. https://doi.org/10.1017/S0033291719003921

Chapman, C., Mills, K., Slade, T., McFarlane, A. C., Bryant, R. A., Creamer, M., Silove, D., \& Teesson, M. (2012). Remission from post-traumatic stress disorder in the general population. Psychological Medicine, 42(08), 1695-1703. https://doi.org/10.1017/S0033291711002856

Christiansen, D. M., \& Hansen, M. (2015). Accounting for sex differences in PTSD: A multi-variable mediation model. European Journal of Psychotraumatology, 6, 1-10. https://doi.org/10.3402/ejpt.v6.26068

Cox, K. S., Resnick, H. S., \& Kilpatrick, D. G. (2014). Prevalence and Correlates of Posttrauma Distorted Beliefs: Evaluating DSM-5 PTSD Expanded Cognitive Symptoms in a National Sample. Journal of Traumatic Stress, 27(3), 299-306. https://doi.org/10.1002/jts.21925 
Darves-Bornoz, J. M., Alonso, J., de Girolamo, G., de Graaf, R., Haro, J. M., KovesMasfety, V., Lepine, J. P., Nachbaur, G., Negre-Pages, L., Vilagut, G., \& Gasquet, I. (2008). Main traumatic events in Europe: PTSD in the European study of the epidemiology of mental disorders survey. Journal of Traumatic Stress, 21(5), 455462. https://doi.org/10.1002/jts.20357

Ehlers, A., Mayou, R. A., \& Bryant, B. (1998). Psychological predictors of chronic posttraumatic stress disorder after motor vehicle accidents. Journal of Abnormal Psychology, 107(3), 508-519. http://dx.doi.org/10.1037//0021-843X.107.3.508

Fazel, S., Khosla, V., Doll, H., \& Geddes, J. (2008). The prevalence of mental disorders among the homeless in western countries: systematic review and meta-regression analysis. PLoS Medicine, 5(12), e225. https://doi.org/10.1371/journal.pmed.0050225

Frazier, P. (2003). Perceived control and distress following sexual assault: A longitudinal test of a new model. Journal of Personality and Social Psychology, 84(6), 1257-1269.

Frese, B., Moya, M., \& Megías, J. L. (2004). Social perception of rape: how rape myth acceptance modulates the influence of situational factors. Journal of Interpersonal Violence, 19(2), 143-161.

Frissa, S., Hatch, S. L., Gazard, B., Fear, N. T., \& Hotopf, M. (2013). Trauma and current symptoms of PTSD in a South East London community. Social Psychiatry and Psychiatric Epidemiology, 48(8), 1199-1209. https://doi.org/10.1007/s00127-0130689-8

Havenaar, J. M., De Wilde, E. J., Van den Bout, J., Drottz-Sjöberg, B. M., \& Van den Brink, W. (2003). Perception of risk and subjective health among victims of the Chernobyl disaster. Social Science and Medicine, 56(3), 569-572. https://doi.org/10.1016/S0277-9536(02)00062-X

Heir, T., Blix, I., \& Knatten, C. K. (2016). Thinking that one's life was in danger: Perceived life threat in individuals directly or indirectly exposed to terror. British 
Journal of Psychiatry, 209(4), 306-310. https://doi.org/10.1192/bjp.bp.115.170167

Johansen, V. A., Wahl, A. K., Eilertsen, D. E., Hanestad, B. R., \& Weisaeth, L. (2006). Acute psychological reactions in assault victims of non-domestic violence: Peritraumatic dissociation, post-traumatic stress disorder, anxiety and depression. Nordic Journal of Psychiatry, 60(6), 452-462. 10.1080/08039480601021886

Keshet, H., Foa, E. B., \& Gilboa-Schechtman, E. (2019). Women's self-perceptions in the aftermath of trauma: The role of trauma-centrality and trauma-type. Psychological Trauma: Theory, Research, Practice, and Policy, 11(5), 542-550. https://doi.org/10.1037/tra0000393

Kilpatrick, D. G., Resnick, H. S., Milanak, M. E., Miller, M. W., Keyes, K. M., \& Friedman, M. J. (2013). National Estimates of Exposure to Traumatic Events and PTSD Prevalence Using DSM-IV and DSM-5 Criteria. Journal of Traumatic Stress, 26(5), 537-547. https://doi.org/10.1002/jts.21848

Kira, I. (2019). Toward an Integrative Theory of Self-Identity and Identity Stressors and Traumas and Their Mental Health Dynamics. Psychology, 10(04), 385-410. https://doi.org/10.4236/psych.2019.104027

Klump, M. C. (2006). Posttraumatic Stress Disorder and Sexual Assault in Women. Journal of College Student Psychotherapy, 21(2), 67-83. https://doi.org/10.1300/J035v21n02_07

Kobasa, S. C., Maddi, S. R., \& Courington, S. (1981). Personality and constitution as mediators in the stress-illness relationship. Journal of Health and Social Behavior, 22(4), 368-378.

Lanius, R. A., Rabellino, D., Boyd, J. E., Harricharan, S., Frewen, P. A., \& McKinnon, M. C. (2017). The innate alarm system in PTSD: conscious and subconscious processing of threat. Current Opinion in Psychology, 14, 109-115.

https://doi.org/10.1016/j.copsyc.2016.11.006 
Lee, D. A., Scragg, P., \& Turner, S. (2001). The role of shame and guilt in traumatic events: a clinical model of shame-based and guilt-based PTSD. British Journal of Medical Psychology, 74(Pt 4), 451-466.

http://www.ncbi.nlm.nih.gov/entrez/query.fcgi?cmd=Retrieve $\& d b=P u b M e d \& d o p t=C i$ tation\&list_uids=11780793

Maercker, A., Michael, T., Fehm, L., Becker, E. S., \& Margraf, J. (2004). Age of traumatisation as a predictor of post-traumatic stress disorder or major depression in young women. The British Journal Of Psychiatry: The Journal Of Mental Science, $184,482-487$.

Müller, M., Ajdacic-Gross, V., Rodgers, S., Kleim, B., Seifritz, E., Vetter, S., Egger, S. T., Rössler, W., Castelao, E., Preisig, M., \& Vandeleur, C. (2018). Predictors of remission from PTSD symptoms after sexual and non-sexual trauma in the community: A mediated survival-analytic approach. Psychiatry Research, 260(October 2017), 262-271. https://doi.org/10.1016/j.psychres.2017.11.068

National Collaborating Centre for Mental Health. (2005). NICE Clinical Guidelines, No. 26. 2, Post-traumatic stress disorder. In The Royal College of Psychiatrists \& the British Psychological Society (Issue 26). https://doi.org/10.1016/j.amepre.2013.01.013

Nordstrand, A. E., Bøe, H. J., Holen, A., Reichelt, J. G., Gjerstad, C. L., \& Hjemdal, O. (2019). Danger- and non-danger-based stressors and their relations to posttraumatic deprecation or growth in Norwegian veterans deployed to Afghanistan. European Journal of Psychotraumatology, 10(1).

https://doi.org/10.1080/20008198.2019.1601989

Olff, M. (2017). Sex and gender differences in post-traumatic stress disorder: an update. European Journal of Psychotraumatology, 8(4), 1351204. https://doi.org/10.1080/20008198.2017.1351204 
Ozer, E. J., Best, S. R., Lipsey, T. L., \& Weiss, D. S. (2003). Predictors of posttraumatic stress disorder and symptoms in adults: A meta-analysis. . Psychological Bulletin, $129(1), 52-73$.

Park, C. L. (2010). Making sense of the meaning literature: An integrative review of meaning making and its effects on adjustment to stressful life events. Psychological Bulletin, 136(2), 257-301. https://doi.org/10.1037/a0018301

Pérez-Sales, P., Eiroa-Orosa, F. J., Olivos, P., Barbero-Val, E., Fernández-Liria, A., \& Vergara, M. (2012). Vivo Questionnaire: A Measure of Human Worldviews and Identity in Trauma, Crisis, and Loss_-Validation and Preliminary Findings. Journal of Loss and Trauma, 17(3), 236-259. https://doi.org/10.1080/15325024.2011.616828

Saraiya, T., \& Lopez-Castro, T. (2016). Ashamed and Afraid: A Scoping Review of the Role of Shame in Post-Traumatic Stress Disorder (PTSD). Journal of Clinical Medicine, 5(11), 94. https://doi.org/10.3390/jcm5110094

Schnyder, U., Moergeli, H., Trentz, O., Klaghofer, R., \& Buddeberg, C. (2001). Prediction of psychiatric morbidity in severely injured accident victims at one-year follow-up. American Journal Of Respiratory And Critical Care Medicine, 164(4), 653-656.

Scott, K. M., Koenen, K. C., King, A., Petukhova, M. V., Alonso, J., Bromet, E. J., Bruffaerts, R., Bunting, B., De Jonge, P., Haro, J. M., Karam, E. G., Lee, S., MedinaMora, M. E., Navarro-Mateu, F., Sampson, N. A., Shahly, V., Stein, D. J., Torres, Y., Zaslavsky, A. M., \& Kessler, R. C. (2018). Post-traumatic stress disorder associated with sexual assault among women in the WHO World Mental Health Surveys. Psychological Medicine, 48(1), 155-167. https://doi.org/10.1017/S0033291717001593

Shalev, A. Y., Gevonden, M., Ratanatharathorn, A., Laska, E., van der Mei, W. F., Qi, W., Lowe, S., Lai, B. S., Bryant, R. A., Delahanty, D., Matsuoka, Y. J., Olff, M., Schnyder, U., Seedat, S., deRoon-Cassini, T. A., Kessler, R. C., Koenen, K. C., 
Errera-Ankri, Y., Barbano, A. C., ... van Zuiden, M. (2019). Estimating the risk of PTSD in recent trauma survivors: results of the International Consortium to Predict PTSD (ICPP). World Psychiatry, 18(1), 77-87. https://doi.org/10.1002/wps.20608

Silove, D., Austin, P., \& Steel, Z. (2007). No Refuge from Terror: The Impact of Detention on the Mental Health of Trauma-affected Refugees Seeking Asylum in Australia. Transcultural Psychiatry, 44(3), 359-393. https://doi.org/10.1177/1363461507081637

Tolin, D. F., \& EB., F. (2006). Sex Differences in Trauma and Posttraumatic Stress Disorder: A Quantitative Review of 25 Years of Research. Psychological Bulletin, 132(6), 959-992.

Tran, H. N., \& Beck, J. G. (2019). Are Peritraumatic Perceptions of Fear/Life Threat and Posttraumatic Negative Self-Conscious Appraisals/Emotions Differentially Associated with PTSD Symptoms? Cognitive Therapy and Research, 43(1), 272-283. https://doi.org/10.1007/s10608-018-9903-Z

Turner, D. S., \& Cox, H. (2004). Facilitating Post Traumatic Growth. Health And Quality Of Life Outcomes, 2, 34.

Ullman, S. E., Filipas, H. H., Townsend, S. M., \& Starzynski, L. L. (2007). Psychosocial correlates of PTSD symptom severity in sexual assault survivors. Journal of Traumatic Stress, 20(5), 821-831. https://doi.org/10.1002/jts.20290

Vazquez, C., Cervellon, P., Perez-Sales, P., Vidales, D., \& Gaborit, M. (2005). Positive emotions in earthquake survivors in El Salvador (2001). Journal of Anxiety Disorders, 19(3), 313-328. https://doi.org/S0887618504000234

Weathers, F. W., Huska, J. A., \& Keane, T. M. (1991). The PTSD Checklist-Civilian Version $(P C L-C)$. National Center for PTSD - Behavioral Science Division.

Weathers, F. W., \& Keane, T. M. (2007). The criterion a problem revisited: Controversies and challenges in defining and measuring psychological trauma. Journal of Traumatic 
Stress, 20(2), 107-121. 
Table 1. Perception of Threat and Perception of Life Impact for each experience.

\begin{tabular}{|c|c|c|c|c|c|c|c|c|c|}
\hline \multirow{2}{*}{ Extreme Experience } & \multirow{2}{*}{$\begin{array}{c}\text { Prevale } \\
\text { nce } \\
\text { general } \\
\text { Sample } \\
(\mathrm{N}, \%)\end{array}$} & \multicolumn{4}{|c|}{$\begin{array}{c}\text { Perceived Threat } \\
(\%)\end{array}$} & \multicolumn{4}{|c|}{$\begin{array}{c}\text { Perceived Impact } \\
(\%)\end{array}$} \\
\hline & & L. & M. & S. & E. & (1) & (2) & (3) & (4) \\
\hline $\begin{array}{l}\text { Road traffic } \\
\text { accidents }\end{array}$ & $\begin{array}{l}983 \\
27.6\end{array}$ & 4.0 & 51.8 & 34.1 & 10.1 & 18.3 & 47.2 & 24.6 & 9.9 \\
\hline Natural catastrophe & $\begin{array}{l}415 \\
11.6\end{array}$ & 2.0 & 59.1 & 29.4 & 9.4 & 19.7 & 51.4 & 18.0 & 10.9 \\
\hline $\begin{array}{l}\text { Death, assault or } \\
\text { beating threats }\end{array}$ & $\begin{array}{c}1.225 \\
34.4\end{array}$ & 4.8 & 52.1 & 34.7 & 8.3 & 7.5 & 42.3 & 32.7 & 17.5 \\
\hline Domestic violence & $\begin{array}{l}704 \\
19.7\end{array}$ & 11.6 & 52.0 & 31.2 & 5.2 & 0.7 & 22.6 & 46.2 & 30.4 \\
\hline $\begin{array}{c}\text { Sexual abuse by a } \\
\text { stranger }\end{array}$ & $\begin{array}{l}181 \\
5.1\end{array}$ & 26.5 & 28.3 & 35.5 & 9.6 & 12.9 & 22.4 & 35.3 & 29.4 \\
\hline $\begin{array}{l}\text { Sexual abuse by } \\
\text { relative or a close } \\
\text { person }\end{array}$ & $\begin{array}{l}231 \\
6.5\end{array}$ & 21.6 & 27.9 & 30.6 & 19.8 & 7.0 & 19.7 & 39.5 & 33.8 \\
\hline $\begin{array}{l}\text { Serious, chronic, or } \\
\text { disabling disease }\end{array}$ & $\begin{array}{l}728 \\
20.4\end{array}$ & 6.2 & 35.6 & 40.1 & 17.9 & 4.5 & 18.6 & 33.3 & 43.4 \\
\hline $\begin{array}{l}\text { Divorce or } \\
\text { separation }\end{array}$ & $\begin{array}{c}1.247 \\
35.0\end{array}$ & 25.3 & 39.3 & 28.2 & 7.2 & 6.5 & 33.4 & 34.3 & 25.8 \\
\hline $\begin{array}{l}\text { Migration for } \\
\text { economic reasons }\end{array}$ & $\begin{array}{l}480 \\
13.2\end{array}$ & 39.7 & 39.0 & 15.0 & 6.3 & 22.4 & 25.7 & 22.7 & 29.2 \\
\hline
\end{tabular}


Table 2.-Summary of Linear Regression Analyses for Variables Correlated with PTSD

\begin{tabular}{|c|c|c|c|c|c|c|c|}
\hline Event & $\begin{array}{l}\text { Variables } \\
\text { included }\end{array}$ & $B$ & $S E B$ & $\beta$ & Model & $\begin{array}{l}\text { Variables } \\
\text { excluded }\end{array}$ & $\begin{array}{c}\rho \\
\text { Spearman } \\
\end{array}$ \\
\hline \multirow{4}{*}{$\begin{array}{l}\text { Road } \\
\text { traffic } \\
\text { accident }\end{array}$} & PI & 3.21 & .74 & $0.18 * * *$ & \multirow{4}{*}{$\begin{array}{l}R^{2=}=0.09 \\
F=13.12^{* * *}\end{array}$} & \multirow{4}{*}{$\begin{array}{l}\text { PT } \\
\text { Age }\end{array}$} & \multirow{4}{*}{$\begin{array}{r}-.008 \\
.17\end{array}$} \\
\hline & Gender & -5.34 & 1.39 & $-.17 * * *$ & & & \\
\hline & ASTE & .54 & .2 & $.11^{* *}$ & & & \\
\hline & Ed. & -2.83 & 1.32 & $-.09 *$ & & & \\
\hline \multirow{5}{*}{$\begin{array}{l}\text { Natural } \\
\text { disaster }\end{array}$} & PI & 4.77 & 1.16 & $.28 * * *$ & $R^{2=}=0.14$ & \multirow{5}{*}{ Age } & \multirow{5}{*}{.17} \\
\hline & ASTE & .61 & .26 & $.15^{*}$ & $F=6.27 * * *$ & & \\
\hline & Gender & -3.92 & 2.17 & -.12 & & & \\
\hline & Ed. & -3.69 & 2.3 & -.1 & & & \\
\hline & PT & 2.35 & 1.61 & .1 & & & \\
\hline \multirow{6}{*}{$\begin{array}{l}\text { Death, } \\
\text { assault } \\
\text { or } \\
\text { beating } \\
\text { threats }\end{array}$} & PI & 4.73 & .69 & $.27 * * *$ & $\begin{array}{l}R^{2}=14 \\
F=2069 * * *\end{array}$ & \multirow{6}{*}{ Age } & \multirow{6}{*}{.17} \\
\hline & Ed. & -3.85 & 1.12 & $-.13 * * *$ & & & \\
\hline & & & & 12** & & & \\
\hline & Gender & 5.02 & 1.2 & -.12. & & & \\
\hline & PT & 1.64 & .81 & $.07 *$ & & & \\
\hline & ASTE & .29 & .16 & .06 & & & \\
\hline \multirow{5}{*}{$\begin{array}{c}\text { Domesti } \\
c \\
\text { violence }\end{array}$} & PI & 4.77 & 1.07 & $.22 * * *$ & $R^{2}=.09$ & \multirow{5}{*}{ Age } & \multirow{5}{*}{.17} \\
\hline & PT & 2.68 & .97 & $.13 * *$ & $F=8.35^{* * *}$ & & \\
\hline & Ed. & -3.05 & 1.42 & $-.1 *$ & & & \\
\hline & ASTE & .34 & .2 & .85 & & & \\
\hline & Gender & 1.1 & 1.62 & .03 & & & \\
\hline \multirow{5}{*}{$\begin{array}{c}\text { Sexual } \\
\text { abuse by } \\
\text { a } \\
\text { stranger }\end{array}$} & Ed. & -7.12 & 2.65 & $-.27 * *$ & $R^{2}=.14$ & \multirow{5}{*}{ Age } & \multirow{5}{*}{.17} \\
\hline & PI & 4.27 & 1.85 & $.27 *$ & $F=3.1^{*}$ & & \\
\hline & Gender & -.79 & 3.31 & -.02 & & & \\
\hline & ASTE & .58 & .46 & .12 & & & \\
\hline & PT & .76 & 1.84 & .04 & & & \\
\hline \multirow{5}{*}{$\begin{array}{c}\text { Sexual } \\
\text { abuse by } \\
\text { a relative } \\
\text { or a } \\
\text { close } \\
\text { person }\end{array}$} & PI & 3.49 & 1.57 & $.21 *$ & $R^{2}=.12$ & \multirow{5}{*}{ Age } & \multirow{5}{*}{.17} \\
\hline & Ed. & -6 & 2.41 & $-.2^{*}$ & $F=3.55^{* *}$ & & \\
\hline & PT & 1.21 & 1.3 & .08 & & & \\
\hline & Gender & -2.27 & 3.11 & -06 & & & \\
\hline & ASTE & -.07 & .32 & -.02 & & & \\
\hline \multirow{5}{*}{$\begin{array}{c}\text { Severe, } \\
\text { chronic } \\
\text { or } \\
\text { disabling } \\
\text { illness }\end{array}$} & PI & 2.93 & .87 & $.16^{* * *}$ & $R^{2}=.1$ & \multirow{5}{*}{ Age } & \multirow{5}{*}{.17} \\
\hline & ASTE & .69 & .19 & $.165 * * *$ & $F=10.02 * * *$ & & \\
\hline & Ed. & -3.55 & 1.35 & $-.12 * *$ & & & \\
\hline & PT & 2.36 & .9 & $.12 * *$ & & & \\
\hline & Gender & -2.72 & 1.48 & -.08 & & & \\
\hline \multirow[t]{2}{*}{$\begin{array}{l}\text { Divorce } \\
\quad \text { or }\end{array}$} & PT & 3.33 & .74 & $.2 * * *$ & $R^{2}=.14$ & \multirow{2}{*}{ Age } & \multirow[b]{2}{*}{.17} \\
\hline & PI & 2.79 & .74 & $.16 * * *$ & $F=19.06^{* * *}$ & & \\
\hline
\end{tabular}




\begin{tabular}{|c|c|c|c|c|c|c|}
\hline $\begin{array}{c}\text { separatio } \\
\mathrm{n}\end{array}$ & $\begin{array}{l}\text { ASTE } \\
\text { Ed. } \\
\text { Gender }\end{array}$ & $\begin{array}{r}.48 \\
-3.31 \\
-2.8 \\
\end{array}$ & $\begin{array}{r}.16 \\
1.11 \\
1.19 \\
\end{array}$ & $\begin{array}{r}.11 * * \\
-.11 * * \\
-.09 * \\
\end{array}$ & & \\
\hline $\begin{array}{l}\text { Migratio } \\
\text { n by } \\
\text { economi } \\
\text { c reasons }\end{array}$ & $\begin{array}{l}\text { Gender } \\
\text { PT } \\
\text { Ed. } \\
\text { ASTE } \\
\text { PI }\end{array}$ & $\begin{array}{r}-7.37 \\
2.94 \\
-5.41 \\
.41 \\
1.23 \\
\end{array}$ & $\begin{array}{r}2.07 \\
1.4 \\
1.77 \\
.28 \\
1.11\end{array}$ & $\begin{array}{r}-.22 * * * \\
.16^{* *} \\
-.19 * * \\
.09 \\
.08 \\
\end{array}$ & $\begin{array}{l}R^{2}=0.16 \\
F=8.32 * * *\end{array}$ & Age \\
\hline
\end{tabular}

NOTE: * $\mathrm{p}<.05 ; * * \mathrm{p}<.01 ; * * * \mathrm{p}<.001 . \mathrm{B}=$ unstandardized beta coefficient; $\mathrm{SE} \mathrm{B}=$ standard error of $\mathrm{B} ; \beta$ $=$ standardized beta coefficient; $\mathrm{R}^{2}=$ coefficient of determination. $\mathrm{PT}=$ Perception of life Threat; $\mathrm{PI}=$ Perception of life Impact; ASTE= Average Score of Traumatic Events; Ed=Education. 
Table 3.-Chi-Square of Self-Perceived Resistance by gender and educational level

\begin{tabular}{|c|c|c|c|c|c|c|c|c|}
\hline \multirow{2}{*}{ Experience } & \multirow{2}{*}{ SPR } & \multicolumn{2}{|c|}{ Gender $(\%)$} & \multirow[t]{2}{*}{$X^{2}(\mathrm{df})$} & \multicolumn{3}{|c|}{ Educational Level (\%) } & \multirow[t]{2}{*}{$X^{2}(\mathrm{df})$} \\
\hline & & Women & Men & & Upper & Middle & Primary & \\
\hline \multirow{4}{*}{$\begin{array}{c}\text { Motor } \\
\text { vehicle } \\
\text { accident }\end{array}$} & S & 21.2 & 16.5 & \multirow[t]{4}{*}{$35.3(3) * * *$} & 19.7 & 15.6 & 25.8 & \multirow[t]{4}{*}{$4.34(6)$} \\
\hline & VB & 22.8 & 10.7 & & 16.2 & 17.5 & 9.7 & \\
\hline & $\mathrm{R}$ & 20.4 & 29.6 & & 23.9 & 28 & 25.8 & \\
\hline & NAF & 35.6 & 43.2 & & 40.2 & 38.9 & 38.7 & \\
\hline \multirow{4}{*}{$\begin{array}{l}\text { Natural } \\
\text { disaster }\end{array}$} & S & 18.7 & 15.2 & \multirow[t]{4}{*}{$25.1(3)^{* * *}$} & 18.3 & 8.7 & 30 & \multirow{4}{*}{$\begin{array}{c}15.16 \\
(6)^{*}\end{array}$} \\
\hline & VB & 21.1 & 6.3 & & 9.8 & 43.5 & 30 & \\
\hline & $\mathrm{R}$ & 14.5 & 27.2 & & 21 & 27.5 & 20 & \\
\hline & NAF & 45.8 & 51.3 & & 43.5 & 20.3 & 20 & \\
\hline \multirow{4}{*}{$\begin{array}{l}\text { Death, } \\
\text { assault or } \\
\text { beating } \\
\text { threats }\end{array}$} & S & 36.5 & 18.6 & \multirow[t]{4}{*}{$97.9(3) * * *$} & 27.8 & 23.5 & 28.1 & \multirow[t]{4}{*}{$3.92(6)$} \\
\hline & VB & 28.8 & 18.6 & & 21.9 & 25.4 & 27.8 & \\
\hline & $\mathrm{R}$ & 9.6 & 22.1 & & 16.4 & 16.6 & 11.1 & \\
\hline & NAF & 25.1 & 40.8 & & 33.6 & 34.5 & 33.3 & \\
\hline \multirow{4}{*}{$\begin{array}{l}\text { Domestic } \\
\text { Violence }\end{array}$} & S & 30.3 & 34.5 & \multirow[t]{4}{*}{$3.6(3)$} & 30.8 & 27.9 & 54.2 & \multirow[t]{4}{*}{$8.95(6)$} \\
\hline & VB & 46.9 & 42.7 & & 45.7 & 41.7 & 41.7 & \\
\hline & $\mathrm{R}$ & 4 & 6.4 & & 4.5 & 5.4 & 0 & \\
\hline & NAF & 18.8 & 16.4 & & 19 & 18.4 & 4.2 & \\
\hline \multirow{4}{*}{$\begin{array}{c}\text { Sexual } \\
\text { assault by a } \\
\text { stranger }\end{array}$} & $S$ & 34.1 & 33.3 & \multirow[t]{4}{*}{$.11(3)$} & 36.1 & 23.1 & 16.7 & \multirow[t]{4}{*}{$7.93(6)$} \\
\hline & VB & 21.4 & 22.2 & & 23.5 & 20.5 & 16.7 & \\
\hline & $\mathrm{R}$ & 12.7 & 11.1 & & 13.4 & 7.7 & 16.7 & \\
\hline & NAF & 31.7 & 33.3 & & 26.9 & 48.7 & 50 & \\
\hline \multirow{4}{*}{$\begin{array}{c}\text { Sexual } \\
\text { assault by a } \\
\text { relative or a } \\
\text { close } \\
\text { person }\end{array}$} & S & 45.2 & 42.2 & \multirow[t]{4}{*}{$6.6(3)$} & 42.5 & 48 & 40 & \multirow[t]{4}{*}{$1.4(6)$} \\
\hline & VB & 31.9 & 20 & & 29.5 & 30 & 40 & \\
\hline & $\mathrm{R}$ & 6 & 4.4 & & 6.2 & 6 & 0 & \\
\hline & NAF & 16.9 & 33.3 & & 21.9 & 16 & 20 & \\
\hline \multirow{4}{*}{$\begin{array}{l}\text { Severe, } \\
\text { chronic or } \\
\text { disabling } \\
\text { disease }\end{array}$} & $S$ & 50.8 & 43.4 & \multirow[t]{4}{*}{$13.4(3)^{* *}$} & 46.8 & 46.2 & 66.7 & $8.73(6)$ \\
\hline & VB & 31.9 & 27.7 & & 31.8 & 26.7 & 20.8 & \\
\hline & $\mathrm{R}$ & 8.2 & 15.1 & & 11 & 13.3 & 0 & \\
\hline & NAF & 9.1 & 13.8 & & 10.4 & 13.8 & 12.5 & \\
\hline & $S$ & 31.6 & 29.2 & $3.8(3)$ & 29 & 30.4 & 31.6 & $6.57(6)$ \\
\hline Divorce or & VB & 31.8 & 28.8 & & 31.2 & 30.4 & 23.7 & \\
\hline separation & $\mathrm{R}$ & 4.9 & 4.8 & & 4.5 & 5.1 & 13.2 & \\
\hline & NAF & 31.6 & 37.2 & & 35.3 & 34.2 & 31.6 & \\
\hline Migration & $S$ & 22.6 & 15.2 & $5.4(3)$ & 16.1 & 24.5 & 19 & $4.22(6)$ \\
\hline for & VB & 32.7 & 32.7 & & 35.1 & 28.6 & 33.3 & \\
\hline economic & $\mathrm{R}$ & 1.5 & 3.6 & & 2.5 & 3.1 & 4.8 & \\
\hline reasons & NAF & 43.2 & 48.4 & & 46.2 & 43.9 & 42.3 & \\
\hline
\end{tabular}

NOTE: $* p<.05 ; * * p<.01 ; * * * p<.001$. S= Survivor; VB= Vulnerable; R= Resistant; NAF= Non-Affected. SPR=Self-Perceived Resistance 
Table 4.-Table X. ANOVA of Self-Perceived Resistance by PTSD scores

\begin{tabular}{|c|c|c|c|c|}
\hline Experience & SPR & $\begin{array}{l}\text { PCL-C } \\
\text { Mean }\end{array}$ & $\mathrm{F}$ & Differences \\
\hline \multirow{4}{*}{$\begin{array}{c}\text { Road } \\
\text { traffic } \\
\text { accident }\end{array}$} & $\mathrm{S}$ & 49.07 & \multirow[t]{4}{*}{$8.4 * * *$} & $\mathrm{~S}=\mathrm{VB}$ \\
\hline & VB & 48.65 & & $S>R \& S>N A F$ \\
\hline & $\mathrm{R}$ & 41.23 & & $V B>R \& V B>N A F$ \\
\hline & NAF & 43.15 & & $\mathrm{R}=\mathrm{NAF}$ \\
\hline \multirow{4}{*}{$\begin{array}{l}\text { Natural } \\
\text { disaster }\end{array}$} & $\mathrm{S}$ & 49.57 & \multirow[t]{4}{*}{$7.2 * * *$} & $\mathrm{~S}=\mathrm{VB}$ \\
\hline & VB & 49.92 & & $S=R \& S>N A F$ \\
\hline & $\mathrm{R}$ & 42.22 & & $\mathrm{VB}=\mathrm{R} \& \mathrm{VB}>\mathbf{N A F}$ \\
\hline & NAF & 38.44 & & $\mathrm{R}=\mathrm{NAF}$ \\
\hline \multirow{4}{*}{$\begin{array}{l}\text { Death, } \\
\text { assault or } \\
\text { beating } \\
\text { threats }\end{array}$} & $\mathrm{S}$ & 52.65 & \multirow[t]{4}{*}{$28.9 * * *$} & $\mathrm{~S}=\mathrm{VB}$ \\
\hline & VB & 49.15 & & $\mathbf{S}>\mathbf{R} \& \mathbf{S}>\mathbf{N A F}$ \\
\hline & $\mathrm{R}$ & 42.18 & & $V B>R \& V B>N A F$ \\
\hline & NAF & 40.18 & & $\mathrm{R}=\mathrm{NAF}$ \\
\hline \multirow{4}{*}{$\begin{array}{l}\text { Domestic } \\
\text { Violence }\end{array}$} & $\mathrm{S}$ & 54.08 & \multirow[t]{4}{*}{$10.7 * * *$} & $S>V B$ \\
\hline & VB & 49.04 & & $S>R \& S>N A F$ \\
\hline & $\mathrm{R}$ & 42.06 & & $\mathrm{VB}=\mathrm{R} \& \mathrm{VB}>\mathbf{N A F}$ \\
\hline & NAF & 42.55 & & $\mathrm{R}=\mathrm{NAF}$ \\
\hline \multirow{4}{*}{$\begin{array}{c}\text { Sexual } \\
\text { assault by } \\
\text { a stranger }\end{array}$} & $\mathrm{S}$ & 53.33 & \multirow[t]{4}{*}{1.4} & $\mathrm{~S}=\mathrm{VB}$ \\
\hline & VB & 50.45 & & $\mathrm{~S}=\mathrm{R} \& \mathrm{~S}=\mathrm{NAF}$ \\
\hline & $\mathrm{R}$ & 49.33 & & $\mathrm{VB}=\mathrm{R} \& \mathrm{VB}=\mathrm{NAF}$ \\
\hline & NAF & 46.53 & & $\mathrm{R}=\mathrm{NAF}$ \\
\hline \multirow{4}{*}{$\begin{array}{c}\text { Sexual } \\
\text { assault by } \\
\text { a relative } \\
\text { or a close } \\
\text { person }\end{array}$} & $\mathrm{S}$ & 52.91 & \multirow[t]{4}{*}{2.6} & $\mathrm{~S}=\mathrm{VB}$ \\
\hline & VB & 52.14 & & $\begin{array}{c}S=V B \\
S=R \& S=N A F\end{array}$ \\
\hline & $\mathrm{R}$ & 43.63 & & $\mathrm{VB}=\mathrm{R} \& \mathrm{VB}=\mathrm{NAF}$ \\
\hline & NAF & 44.77 & & $\mathrm{R}=\mathrm{NAF}$ \\
\hline \multirow{4}{*}{$\begin{array}{l}\text { Serious, } \\
\text { chronic or } \\
\text { disabling } \\
\text { disease }\end{array}$} & $\mathrm{S}$ & 51.08 & \multirow[t]{4}{*}{$9.53 * * *$} & $S>V B$ \\
\hline & $\mathrm{VB}$ & 44.84 & & $S>R \& S>N A F$ \\
\hline & $\mathrm{R}$ & 41.43 & & $\mathrm{VB}=\mathrm{R} \& \mathrm{VB}=\mathrm{NAF}$ \\
\hline & NAF & 42.69 & & $\mathrm{R}=\mathrm{NAF}$ \\
\hline \multirow{4}{*}{$\begin{array}{l}\text { Divorce or } \\
\text { separation }\end{array}$} & $\mathrm{S}$ & 52.44 & \multirow[t]{4}{*}{$26.809 * * *$} & $S>V B$ \\
\hline & VB & 44.02 & & $\mathbf{S}>\mathbf{R} \& \mathbf{S}>\mathbf{N A F}$ \\
\hline & $\mathrm{R}$ & 43.72 & & $\mathrm{VB}=\mathrm{R} \& \mathrm{VB}=\mathrm{NAF}$ \\
\hline & NAF & 40.36 & & $\mathrm{R}=\mathrm{NAF}$ \\
\hline \multirow{4}{*}{$\begin{array}{l}\text { Migration } \\
\text { for } \\
\text { economic } \\
\text { reasons }\end{array}$} & $\mathrm{S}$ & 52.02 & \multirow[t]{4}{*}{$3.945 * *$} & $\mathrm{~S}=\mathrm{VB}$ \\
\hline & VB & 44.78 & & $\mathbf{S}=\mathrm{R} \& \mathbf{S}>\mathbf{N A F}$ \\
\hline & $\mathrm{R}$ & 32 & & $\mathrm{VB}=\mathrm{R} \& \mathrm{VB}=\mathrm{NAF}$ \\
\hline & NAF & 43.72 & & $\mathrm{R}=\mathrm{NAF}$ \\
\hline
\end{tabular}



FIGURES

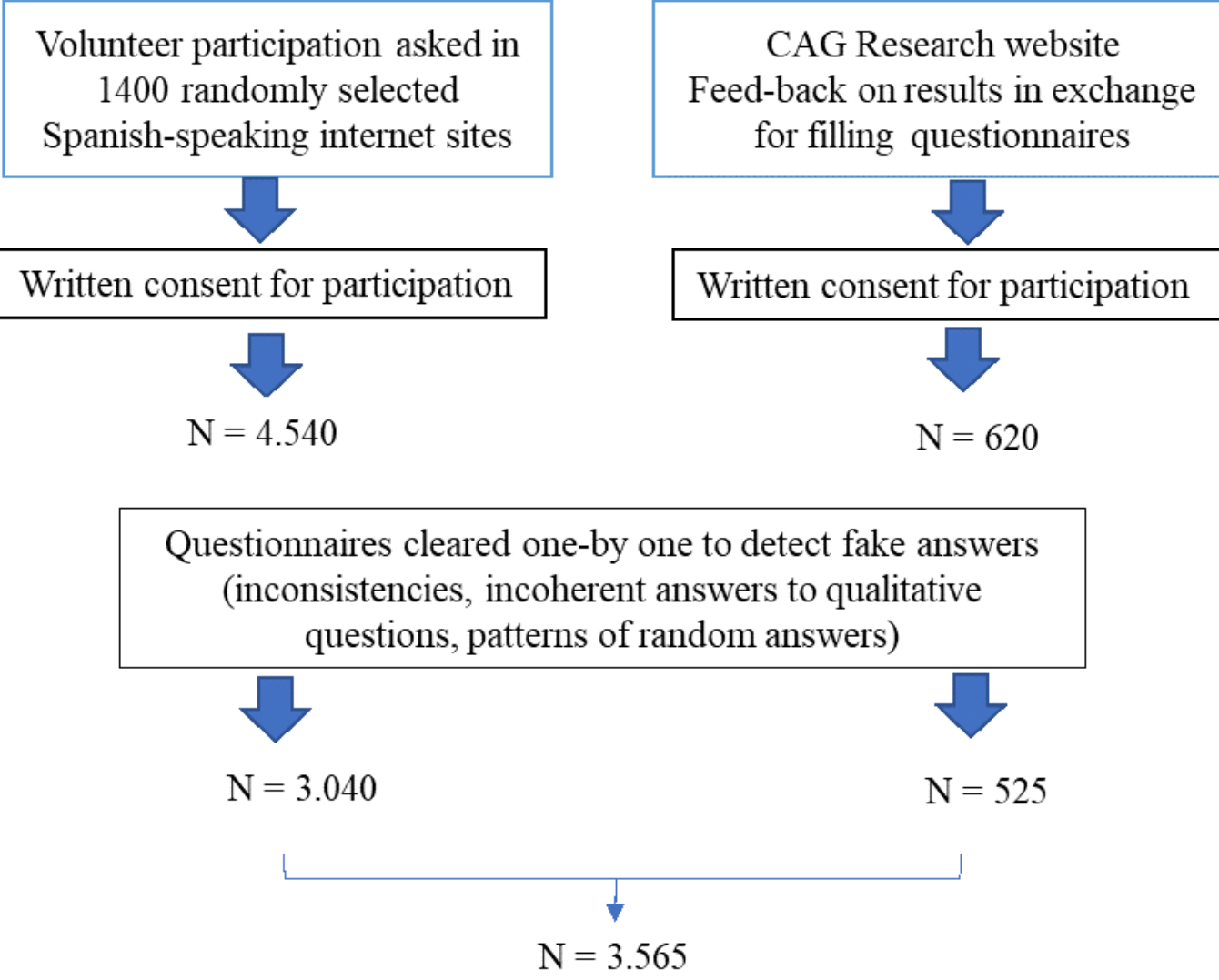

Figure 1. Sampling procedures

\begin{tabular}{|c|c|c|c|}
\hline & & \multicolumn{2}{|c|}{$\begin{array}{l}\text { Perception of physical life Threat } \\
\text { (PT) }\end{array}$} \\
\hline & & Low / Medium & Severe / Extreme \\
\hline \multirow{2}{*}{$\begin{array}{l}\text { Perception } \\
\text { of life } \\
\text { Impact } \\
\text { (PI) }\end{array}$} & $\begin{array}{l}\text { (1) I do not consider myself } \\
\text { affected } \\
\text { (2) I was affected at the time } \\
\text { but not anymore }\end{array}$ & Non-affected & Resistant \\
\hline & $\begin{array}{l}\text { (3) There are aspects that } \\
\text { still strongly affect me } \\
\text { (4) The experience has } \\
\text { decisively changed my way of } \\
\text { viewing life }\end{array}$ & Vulnerable & Survivor \\
\hline
\end{tabular}

Figure 2. Perceived Resistance Indicator (PRI). 


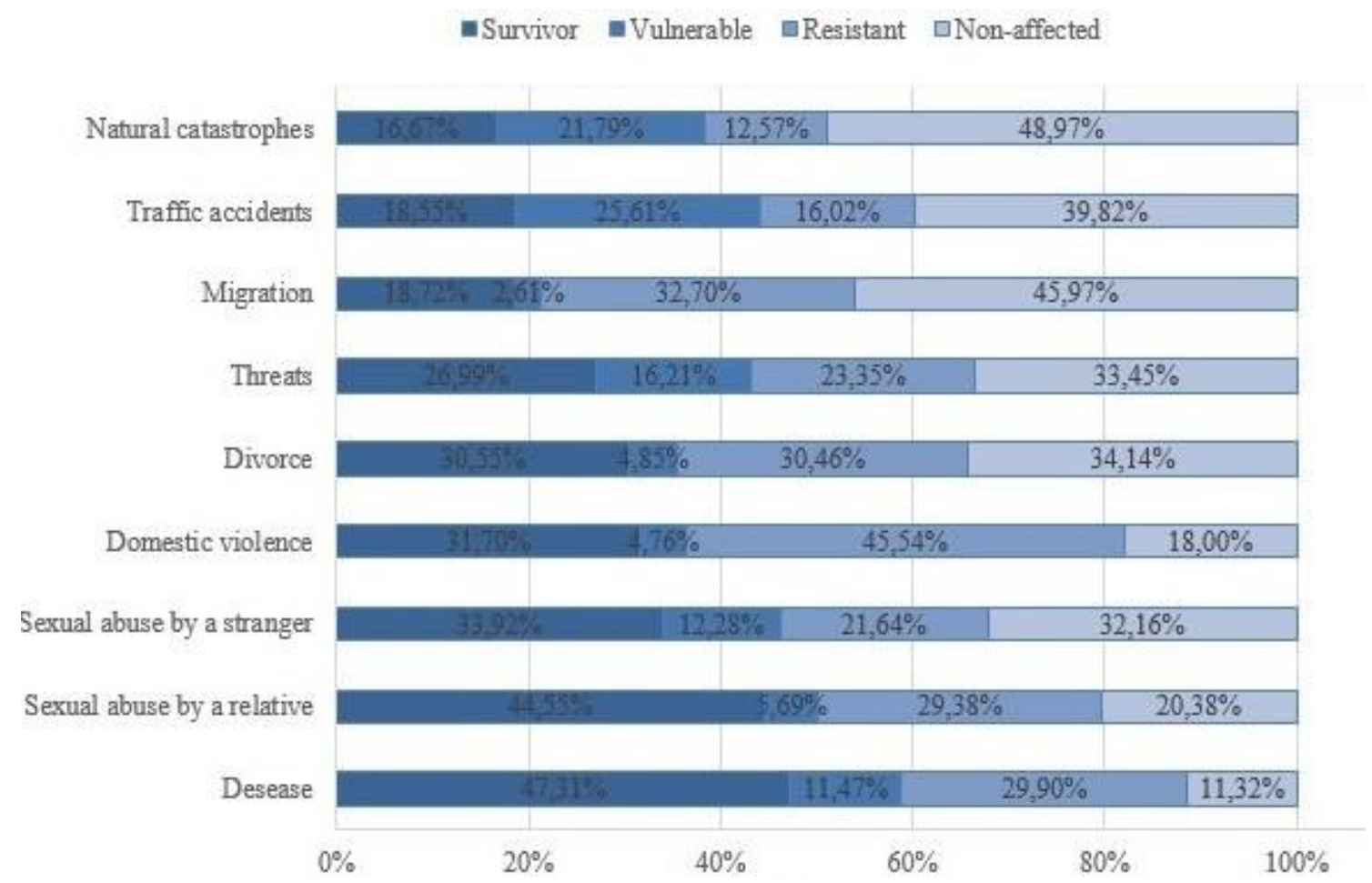

Figure 3. Percentages for each Self-Perceived Resistance (SPR) category in all extreme experiences. 